Article

\title{
Transitioning of Steel Producers to the Steelworks 4.0-Literature Review with Case Studies
}

\author{
Bożena Gajdzik 1,*(D) and Radosław Wolniak ${ }^{2}$ (D) \\ 1 Department of Industrial Informatics, Silesian University of Technology, 40-019 Katowice, Poland \\ 2 Department of Organization and Management, Silesian University of Technology, 41-800 Zabrze, Poland; \\ radoslaw.wolniak@polsl.pl \\ * Correspondence: bozena.gajdzik@polsl.pl
}

Citation: Gajdzik, B.; Wolniak, R. Transitioning of Steel Producers to the Steelworks 4.0-Literature Review with Case Studies. Energies 2021, 14, 4109. https://doi.org/10.3390/ en14144109

Academic Editor: Valentina Colla

Received: 27 May 2021

Accepted: 5 July 2021

Published: 7 July 2021

Publisher's Note: MDPI stays neutral with regard to jurisdictional claims in published maps and institutional affiliations.

Copyright: (c) 2021 by the authors. Licensee MDPI, Basel, Switzerland. This article is an open access article distributed under the terms and conditions of the Creative Commons Attribution (CC BY) license (https:/ / creativecommons.org/licenses/by/ $4.0 /)$.

\begin{abstract}
The publication presents a picture of modern steelworks that is evolving from steelworks 3.0 to steelworks 4.0. The paper was created on the basis of secondary sources of information (desk research). The entire publication concerns the emerging opportunities for the development of the steel producers to Industry 4.0 and the changes already implemented in the steel plants. The collected information shows the support environment for changes in the steel sector (EU programs), the levels of evolution of steel mills, along with the areas of change in the steel industry and implemented investment projects. The work consists of a theoretical part based on a literature review and a practical part based on case studies. The work ends with a discussion in which the staged and segmented nature of the changes introduced in the analyzed sector is emphasized. Based on the three case studies described in the paper, a comparative analysis was conducted between them. When we tried to compare methods used in the three analyzed steel producers (capital groups): ArcelorMittal, Thyssenkrupp, and Tata Steel Group, it can be seen that in all organizations, the main problem connected with steelworks 4.0 transition is the digitalization of all processes within an organization and in the entire supply chain. This is realized using various tools and methods but they are concentrated on using technologies and methods such as artificial intelligence, drones, virtual reality, full automatization, and industrial robots. The effects are connected to better relations with customers, which leads to an increase in customer satisfaction and the organizations' profit. The steel industry will undergo further strong changes, bringing it closer to Industry 4.0 because it occupies an important place in the economies of many countries due to the strong dependence of steel producers on the markets of the recipients (steel consumers). Steel is the basic material needed to make many products, and its properties have been valued for centuries. In addition, steel mills with positive economic, social, and environmental aspects are part of the concept of sustainability for industries and economies.
\end{abstract}

Keywords: Industry 4.0; steelworks 3.0; steelworks 4.0; changes; digitalization

\section{Introduction}

The genesis of Industry 4.0 is connected with the Fourth Industrial Revolution (German: Industrie 4.0). It is assumed that this is a new development concept referring to the changes that will be introduced in the industry in the coming years, based on strong interactions of automation, processing, and data exchange in smart factories [1]. Industry 4.0 is the strong cooperation of operational technology (OT) and information technology (IT) in production [2]. The term "Industry 4.0" was proposed in 2011 by Henning Kagermann, and evolved into a development strategy of the German industry [3,4]. Industry 4.0 uses the technical achievements of the Third Industrial Revolution: automation and digitization. Industry 4.0 is a new phase of the Industrial Revolution. In this phase, organizations focus on the interconnectivity of the following topics: machine learning, automation, real-time data, smart manufacturing, and digital factory. Industry 4.0 is also connected with investing in 
new technology and tools to improve manufacturing efficiency. In this way, organizations can revolutionize the way the whole business grows [5].

The ongoing fourth digital revolution is entering many industrial sectors worldwide. The adoption of a smart manufacturing strategy by aligning to the Industry 4.0 framework enables the steel industry to achieve an integrated, real-time decision-oriented organization. At the current stage of change, the industrial revolution in steel mills is focused on the "deep" automation of production and logistics, more and more often with the use of intelligent IT networks facilitating the implementation of processes and machine communication. In the future, the changes will result in a smart steel plant operating in cyber-physical systems (CPS). The features of the steelworks, apart from the aforementioned "full" automation and the long-term standardization and visualization of processes, are also the visibility of operations, modularity of systems, networking in the supply chain, the flexibility of production, connectivity, autonomy, cyber-physicality, self-optimization, and self-improvement. Such visions of changes in the steel sector are discussed by politicians (projects and programs of European Commission for steel industry), scientists [6,7], and practitioners (studies BCG, PwC, McKinsey, Deloitte) [8-11]. These studies have pointed out the especially important role of digitalization in the process of the implementation of Industry 4.0 in steel mills [12,13]. In this process, the most important factor is also connected with the role of appropriate personnel who are trained to work in the changing environment $[14,15]$. The ongoing discussion was the inspiration in writing this article. The results of the discussion are presented in the paper.

The steel industry is one of the biggest manufacturing industries existing from the times of the first industrial revolution. Up until now, this industry is still functioning and important. However, there is now a need to adjust this industry to the new Industry 4.0 conditions. There is a research gap in the literature about the characteristics of Industry 4.0 in steel organizations, and can be named as steelworks 4.0 [16-18]. The problem with differences between steelworks 3.0 and steelworks 4.0 is not well described in the international literature and is still worth investigating $[5,19,20]$. Especially important and interesting are problems connected with the digitalization of the steel industry. Digitalization is very important because it is a background indispensable to the implementation of KET's technologies in steelworks [6,7]. Following Peters [6,7], it can be assumed that digitalization is a key stage in the transformation of steel producers to operate in Industry 4.0. The steelworks 4.0 in our paper reflects the implementation of key technologies of Industry 4.0, but the extent of change varies from one steelworks to another.

Based on the identified research gap, the following goals of the paper were as follows:

- Present the key EU support for the steel industry.

- Compare steelworks 3.0 and steelworks 4.0.

- Describe the surroundings for the steelworks 4.0.

We analyzed and compared the case study from the steel industry to identify the main activities that organizations are conducting to transform to steelworks 4.0.

In the analysis, we used case studies of three large capital groups representing the global steel industry: ArcelorMittal, Thyssenkrupp, and Tata Steel. The choice of the three capital groups was dictated by their importance for the development of the steel industry through their shares in world steel production and their activity as beneficiaries of EU projects addressed to the industry. Concerning the analysis, such questions were formulated:

- $\quad$ Q1: To what extent are the surveyed organizations implementing changes that will transform them to steelworks 4.0?

- Q2: Which business areas are changing leading to the steelworks 4.0 being implemented?

- Q3: Is the extent of changes in the studied companies comparable?

The answers to these questions are the main contributions of the paper.

In the paper, we tried to give the reason for the answers. To do this, we first analyzed the situation connected with steelworks 4.0 in European Union countries. Next, on this 
basis, we present the problems connected with the industrial development of steelworks. Toward this point, we analyze the historical information about the path of steelworks from steelworks 1.0 to steelworks 4.0. The next point concentrates on the analysis of the changes between steelworks 3.0 and steelworks 4.0. We describe, in a detailed way, the fields of changes and directions of these changes. The third section concentrates on a material and method analysis. The fourth and five sections of the paper contain an analysis of the case studies of changes in three steelworks in the process of transformation from steelworks 3.0 to steelworks 4.0. We analyzed three organizations: ArcelorMittal, Thyssenkrupp, and Tata Steel.

\section{Literature Review}

\subsection{European Union Support for Steelworks 4.0}

For several years, advanced technologies for Industry 4.0 (ATI) such as cloud computing, big data, Internet of Industrial Things (IoT), smart factories, robotics, and 3D printing are the necessary conditions to increase the productivity of industries in highly developed countries [21,22]. The technologies of the Fourth Industrial Revolution are an opportunity for the development of the current Industry 3.0 to Industry 4.0. The governments of highly developed countries have made Industry 4.0 an economic priority in the pursuit of increasing the productivity and competitiveness of economies, societies, and industries. Although the specific policies of countries differ in terms of the scope of activities, financing sources, and implementation paths, the main (basic) goal is a steel Industry 4.0. A decade has passed since the name Industrie 4.0 was used at the Hanover Fair in 2011 and the first implementation recommendations for the industry with the use of high technologies (HTs) were developed [23,24]. The first German platform "Industrie $4.0^{\prime \prime}$ inspired other governments in the EU to create their platforms. The description of the platforms of particular countries is available on the website [25]. Clusters are also a form of cooperation for many organizations. The structure of the European cluster collaboration, established by the European Commission, is made up of sixteen technologies: advanced manufacturing technology, advanced materials, artificial intelligence, augmented and virtual reality, big data, blockchain, cloud computing, connectivity, industrial biotechnology Internet of Things, micro- and nanoelectronics, mobility, nanotechnology, photonics robotics, and security [26]. The scope of cooperation between various organizations in the $\mathrm{EU}$ is increasingly expanding to countries outside the EU: the USA, Japan, and China [27]. From the general policy of popularizing Industry 4.0, European institutions and national governments are moving to industry (industrial) policies. Basic recommendations for implementing changes toward Industry 4.0 have been developed for individual industries, especially those of key importance for the development of the economy. Steel production is one of the important sectors for economic growth. According to PwC research, the steel sector is now considered crucial to industrial production due to the extensive use of steel in processing [28].

The buyers of steel products are the automotive industry, construction, infrastructure, energy, manufacturers of machinery and industrial equipment, household appliances, etc. The determinant of innovation in the European steel industry in recent years are shorter and shorter production cycles. This advantage builds the advantage of this sector over other markets. The steel sector in the EU offers high-quality products. In order to stay ahead of the technological curve of non-EU steel industries, it is necessary to invest in new processes and technologies. This is clearly stated in the communication: "Steel: Preserving sustainable jobs and growth in Europe" published in March 2016 [29] and reiterated in: "A new industrial strategy for Europe" [30] and in: "Action Plan for a Competitive and Sustainable Steel Industry in Europe" [31].

Industry 4.0 is also supported by the activities of the working groups, bringing together scientists and producers (e.g., the Smart Factory of the ESTEP (European Steel Technology Platform) platform, founded in 2008, formerly known as Intelligent Integrated Manufacturing) [32]. The group published the first edition of the Action Plan for European 
Steel Production in 2009 with a vision for 2020. The next visions are until 2025 and 2030. The ESTEP working group consists of manufacturers, universities, and research and development (R\&D) institutions. In 2018, a workshop on the concept and operational benefits of digital twins in the steel sector was held in Charleroi [32,33]. Examples of other working groups are Industrie 4.0 (2014) and ESTEP (2008). The largest steel mills and capital groups such as Tata Steel and ArcelorMittal participate in the above-mentioned working groups. Most of the initiatives are based on research and programs and projects carried out for several years. For many years, the steel industry has been involved in a range of political activities, $R \& D$ projects, and patents in the field of digitization that preceded Industry 4.0 [15]. Digitization has been carried out for many years (since the beginning of the 1990s, and projects have been implemented related to various aspects of the digitization of the steel industry) $[19,34]$. Investments in this area create (build) the environment for Industry $4.0[35,36]$.

The development of the industry is supported by the EU budget under their programs. In recent years, steel mills have used the following programs: RFCS (Research Fund for Coal and Steel), 7 Program (FP7), Horizon 2020, and EUREKA. The activities of the smelters are included in the final reports prepared by the European Commission (RFCS, 2003-2014, [36] RFCS, 2015-2017 [37], FP7 2007-2013 -CORDIS 2018 [38], FP7 2014-2020 [39]). The largest capital groups, for example, ArcelorMittal, Tata Steel, Thyssenkrupp, actively participate in change projects (these mills were mentioned in the final reports: RFCS for 2003-2014; RFCS 2015-2016; in the EUREKA program-1989-2018) [40,41]. Examples of projects include TrackOpt (RFCS), Quality 4.0 (RFCS), NewTech4Steel (RFCS), Cyberman 4.0 (RFCS), CyberPOS (RFCS), Dromosplan (RFCS), RoboHarsh (RCFS, Adopt EAF, (RFCS), SOP rod (RFCS), Opti Scrap Manage (RFCS), I2MSteel (RFCS), Desdemona (RFCS), Dynergy Steel (RFCS), GASnet (RFCS), Plant Temp (RFCS), Auto Adapt (RFCS), Infomap (RFCS), AREUS (7PR), SPIRESPIRE (Sustainable Process Industry through Resources and energy efficiency) (H2020), Water Watt (H2020), FACTS 4 WORKERS (H2020), Dillinger, SSAB, ENCOP, IDEOGAS, LoCO2Fe, PRESED, and IConSys (these two last are companies projects). The initiative of the European Commission is also the European Steel Skills Agenda (ESSA) adopted in January 2019 [42]. The program includes analyses of educational programs, labor market research, descriptions of staff development programs in the largest steel mills in Europe. The result is a pilot development of modules and tools to build awareness and implement new skills for steel industry workers (Blueprint, May 2020) [43]. The project aims to create a steel industry-led, sustainable, and coordinated action plan to respond to economic, digital, and technological developments as well as increasing energy efficiency and environmental requirements by continuously updating the qualifications, knowledge, and skills profiles of the workforce. Research carried out (for the project) confirms the fact that the steel industry foresees the implementation of almost all Industry 4.0 technologies not only to improve competitiveness, but also to protect the environment. Technological change will be incremental and accompanied by changes in the skills of the workforce (upgrading the skills of the existing workforce is a prerequisite, not only because of recruitment difficulties in the labor market, but also because existing skills and experience in the workplace are necessary to develop the full potential of digital and green transformation) [43].

In summary, the above-mentioned European programs, platforms, clusters, and agendas create conditions for the transformation of the steel industry to level 4.0. The initiatives, programs, and projects of the European Commission stimulate steel producers (steel mills) to act toward steelworks 4.0. Steel mills are participants in working groups, program beneficiaries, and participants in projects created by cooperation between industry and science.

\subsection{Industrial Development of the Steelworks}

In the history of the development of metallurgy, in line with successive industrial revolutions, four levels of steel producing development can be distinguished: steelworks 1.0, steelworks 2.0, steelworks 3.0, and steelworks 4.0 [12]. In steelworks 1.0, work was done with simple tools and the steel mills evolved from manual work to industrial steel process- 
ing. The introduction of coal-fired steam engines was the first major change to industrial processes. The invention increased work efficiency. During the first industrial revolution, the first interactions between workers and machines were created. In the nineteenth century, steelworks 2.0 was created as a result of the second industrial revolution, which was marked by the invention of the production line and the improvement of transport technologies and the electrification of industrial processes. In 1856, H. Bessmer invented the first pear-shaped steel converter (the so-called Bessmer pear) [44]. In 1864, the French metallurgist P.É. Martin developed the process of smelting steel in a regenerator furnace [45]. The third stage of metallurgy development-Steelworks 3.0 - started in 1970 with the advent of numerical control machines and the trend of production automation. Both steelworks 1.0 and steelworks 2.0 are history, and steelworks 3.0 is in place until now. Steelworks 3.0 in highly developed countries is changing into steelworks 4.0 [12]. The strengths (strengths) of the mills of the future are "deep" automation, digitization, virtual simulations, real-time data processing, machine communication, and artificial intelligence $[46,47]$. In the future, the steel mills will operate in cyber-physical systems with autonomous production and technology capable of self-optimization and self-improvement of processes [14]. Zeman points out that the steel industry is now halfway between steelworks 3.0 and steelworks 4.0 [12]. In steelworks 4.0, machines run autonomously with little or no human intervention. The plants operate as cyber-physical systems (CPS). The Industrial Internet of Things (IIOT) facilitates the exchange of information from sensors of devices (machines). The system works in real-time and sends data to a local server or cloud server, where data analysis is performed and models are built [48]. Peters [6] lists several stages of Industry 4.0 development in the steel mills as follows:

- $\quad$ single plant as a cyber-physical production system (CPPS and vertical integration);

- full traceability of intermediate and end products in the value chain;

- "intelligent" product with knowledge of its quality and history of production (one of the aspects of end-to-end engineering);

- intensive communication of plants (integration within the company);

- intensive communication along the entire supply chain (integration outside the steelworks);

- $\quad$ proper handling and use of all data;

- decentralization of decisions (de-central) instead of central solutions; and

- self-organization of the system.

Peters stipulates that "Industry 4.0 is an evolution, not a revolution." Currently, mills are at the beginning of a long-term evolution with steelworks 3.0 to steelworks 4.0. Industrial companies understand the benefits of Industry 4.0, but it takes time to transform steelworks 3.0 to steelworks 4.0 [6]. Peters says that right now, it is necessary to develop methods and concepts for the idea of Industry 4.0 and find the best Industry 4.0 applications for the steel industry [7]. In the transformation to steelworks 4.0, an important step is the creation of cyber-physical production systems (CPPS) from individual production sites and their subsequent integration into a chain or chains of cyber-physical systems (Figure 1). 


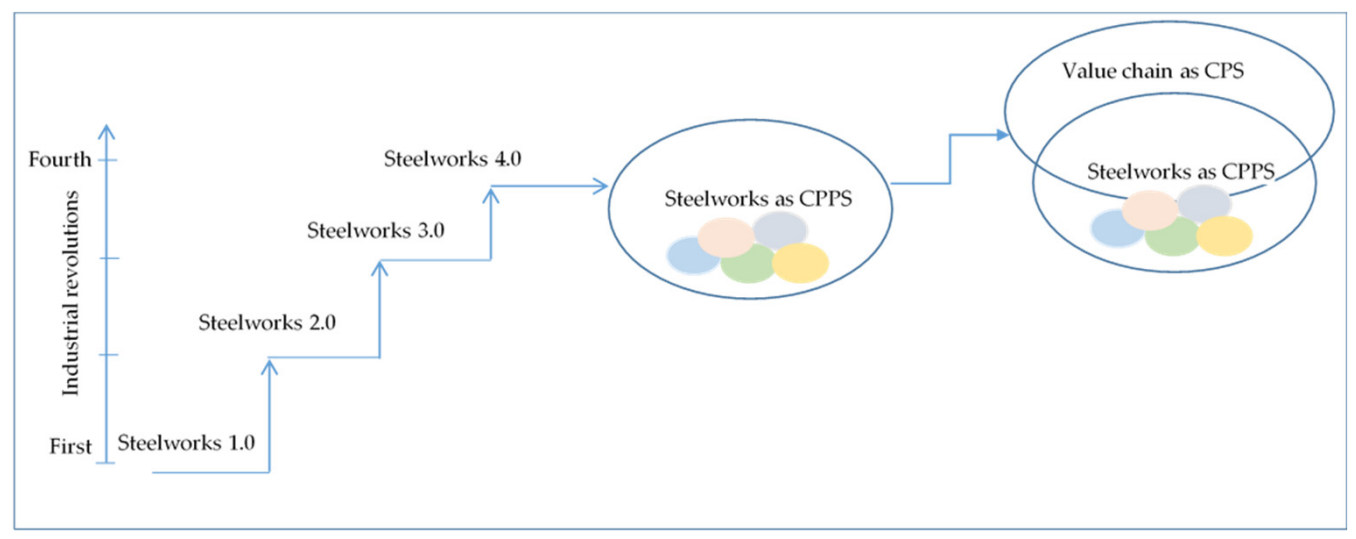

Figure 1. Development of steelworks. Source: Own study.

\subsection{From Steelworks 3.0 to Steelworks 4.0-Key Fields of Changes}

According to Peters [7], "Industry 4.0 is more a paradigm, it is a philosophy than a technology", so it is difficult to identify a specific set of solutions that the steel industry should implement. Industry 4.0 technology is not fully homogeneous; it is a set of technologies (KETs - key enabling technologies). Key enabling technologies (KETs) are an EU policy concept that was introduced in 2009 to stimulate research and innovation in novel and complex technologies to boost industrial competitiveness and to promote European re-industrialization (European Parliament) [49]. The KETs were used in Horizon 2020. The key technologies of Industry 4.0 are the Internet of Things (IoT), Internet of Services (IoS), Big Data with Big Data Analytics, advanced simulation, cloud computing, augmented reality, learning machines, cognitive computing, additive manufacture, printing 3D, autonomous robots/cobots, digital twins, smart manufacturing, autonomous production systems, cyber-physical systems (CPS), and universal integration in value chains and cybersecurity. Base technologies are classified as the nine pillars of Industry 4.0: IoT, systems integration, simulation, augmented reality, big data, additive manufacture, autonomous system, cloud computing, and cybersecurity [50-52]. Other technologies and solutions of Industry 4.0 such as servicing, visualization, and customization are recognized as sub-categories or sub-pillars [13,50-52]. There are so many solutions of Industry 4.0 that Culot et al. [53] attempted to organize all solutions into an interaction matrix $(2 \times 2)$ built from four clusters:

- Physical-digital interface technologies;

- Network technologies;

- Data-processing technologies; and

- Physical-digital process technologies.

In the matrix, key enabling technologies are clustered by the nature of their technical elements and network connectivity. All new technologies together create the cycle: physicalto-digital-to-physical world [54]. The variety of technologies used influences the stage (gradualness) and even the selectivity of applications (use) of individual innovations in the steel industry. The key (possible) areas of change are presented in Table 1. The structure of the table consists of technologies and solutions used in steelworks 4.0 compared to steelworks 3.0. The compilation was based on the characteristics of KETs (key enabling technologies of Industry 4.0). 
Table 1. Characteristics of steelworks 3.0 and steelworks 4.0.

\begin{tabular}{ccc}
\hline $\begin{array}{c}\text { Field } \\
\text { of Change }\end{array}$ & $\begin{array}{c}\text { Direction } \\
\text { of Change }\end{array}$ & $\begin{array}{c}\text { Characteristics of } \\
\text { Steelworks } 3.0\end{array}$ \\
\hline $\begin{array}{c}\text { Integration of technical } \\
\text { processes and } \\
\text { IC systems }\end{array}$ & $\begin{array}{c}\text { ICT, IC systems, } \\
\text { information flows }\end{array}$ & autonomous processes \\
\hline Processes organization & $\begin{array}{c}\text { process visualization, } \\
\text { process control, } \\
\text { monitoring, } \\
\text { process optimization }\end{array}$ & $\begin{array}{c}\text { process optimization, } \\
\text { digitalization of physical } \\
\text { processes, virtualization, } \\
\text { statistics and quality control } \\
\text { systems, process monitoring }\end{array}$ \\
\hline
\end{tabular}

Humans and machines

towards automatization and robots

operator of machine (P2M),

Total Productive Maintenance

\section{Characteristics of \\ Steelworks 4.0}

autonomous decision processes, learning functions to adapt technical processes and IT systems

self-optimization, programmable logic controller (PLC), virtual assistance digital transformation end-end digital integration, simulation and virtualization, learning function, intelligent plant monitoring

machine and machine (M2M), learning machines, artificial intelligence, smart maintenance, RFID (product-machine), smart sensors, self-organized, symbiosis of human and machine: Human CPS (H-CPPS)

Internet: broadband Internet,

netwerconnection information sharing
Communication and connection

Data process integration of text data, video-/audio-streams and others, real time data, open data, smart data, integrated data coming from

different sources mobile Internet, websites networking, interoperability, vertical integration of production systems, horizontal integration of partners in value chain,

integration inside and outside, collaboration network

IoT, IIoT, IoS, intensive networking, intensive communication,

interoperability, networked and distributed data diffusion, vertical integration of production systems, horizontal integration of partners in value chain (via value creation networks), smart chains

Big Data, Big Data Analytics, cloud computing, IoT (IoPeople, IoEverything, IoData),

IT systems integration of IT systems, ERP

System of Systems (SoS),

Web-Based Organization, smart product-RFID, product information management, High Performance Computing (HIP), DevOps

decentralized decisions, decision support systems (DSS), networked, distributed data diffusion, online decisions decentralized decisions, process organization central solutions

full automatization,

robots, AI

classic automatization

Automatization

Production and materials planning

smart production, CPPS
TQM, ERP, pull systems, embedded systems process automation/control, collaborative robots, cobots, AI-Artificial Intelligence, Automated Guided Vehicles-AGV

CPPS, additive manufacturing (AM), 3D printing, process simulation and modeling, new materials, energy management solution personal design, simultaneous planning of products and production process, digital twin personal product, co-innovation, IoS, intelligent product with knowledge of its own quality and production history, end-to-end engineering, individual innovation for personal product, block chain technology, smart factory, diversification, product innovation, services, sustainability personalization ecosystem 


\subsection{Surroundings of Steelworks 4.0}

The evolution of steel mills toward Industry 4.0 should be consistent with the functions of steel mills in the economy and society. Changes introduced in mills are expected to reduce the labor and resource intensity of industrial activities, while increasing efficiency, reducing costs, and enhancing sustainability. According to Santos et al. [13], the relations between factories and the environment at the stage of transformation to Industry 4.0 are as follows: "Factory and Nature", "Factory and Local communities", "Factory and Value chains", and "Factory and Humans". Thus for the steel industry, such relations are built: the steelworks and nature; the steelworks and local communities; the steelworks and value chains; and the steelworks and humans. The relations of metallurgy with the environment are presented in Figure 2. The individual areas of relations are linked by the economic, social, and ecological "lens". The image of transformation using a lens more easily reflects the steel sector's drive toward cost reduction, sustainability, and social responsibility [55].

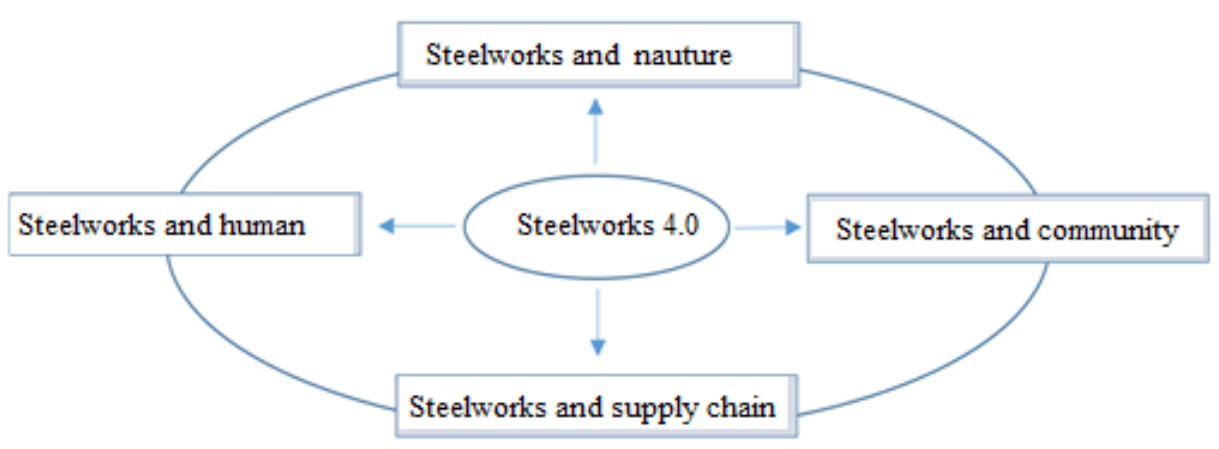

Figure 2. Surroundings for the steelworks 4.0. Reproduced from Santos et al., MESIC 2017, Vigo (Pontevedra), Spain 2017 [13].

The purpose of the relations between the steelworks and nature is to reduce the negative and increase the positive impacts (aspects) of the steel industry on the natural environment. Investments made in recent years have reduced the arduousness of the steel industry. Technological innovation is woven into sustainability. Sustainability is necessary for Industry 4.0 to maintain aspects of economic, social, and environmental balance [56]. The key environmental aspects have been identified by steel plants and environmental strategies are being realized by them [57]. In its efforts to achieve sustainability, the steel sector still needs to limit its resource consumption and pollutant emissions. The steel sector is energy-intensive and steel production generates significant amounts of carbon dioxide. Reducing the negative impact of the steel industry on the environment is the subject of plans and activities of the European Commission [58]. In the future, the sector is to be low-emission and energy-efficient. Steel recycling is an opportunity for Industry 4.0. Steel remains one of the most durable and versatile materials available. Steel products have a very long service life and can be transformed and re-incorporated into steel production several times.

Regarding the relationship between the steelworks and society, activities for the benefit of corporate social responsibility (CSR) that started in the 1990s will be continued [59]. Apart from the issue of SR, the personalization of products and customization will be new challenges for steelworks. These processes enable better matching of products to the needs of customers and their greater involvement in the design and even manufacturing processes. Currently, both mega [60] and micro-mills [61] operate on the steel market. Varying plant sizes are expected to increase customer acceptance and strengthen plant ties with local communities.

In the logistic relationship of the steelworks in the value chain, building value for customers is of great importance. The new relations are supported by the strong trust [62] In Industry 4.0, the processes of supply, production, storage, and distribution are more 
flexible, thus creating opportunities for strong links between products and services and markets (customers) [63,64]. The new models of cooperation are built [65,66]. In Industry 4.0, cyber-physical technologies improve process control, communication, customization, quality improvement, and innovation.

The last area concerns the relationship between the steelworks and humans. For years, mills have appreciated the know-how of their employees, whose knowledge and experience will be used in the evolution of the steelworks from level 3.0 to 4.0 [67]. However, when building steelworks 4.0, it is already necessary to develop the employees' skills to obtain "skills 4.0". In smart steel mills, people will not be looking for solutions to problems, but devices, and people will work with them. In Industry 4.0, a human (employee) is included in cyber-physical systems and creates with them: human-cyber-physical systems (H-CPS) $[68,69]$. The interaction of the worker with machines is a vast topic and already constitutes a separate additional stage of research [70,71]. After a decade since the conception of Industry 4.0, politicians, scientists, and practitioners have noticed that the human being must be at the center of the CPS. In January 2021, the EC published a paper on the key paradigms of Industry 5.0 [72]. Referring to this construct (H-CPS), the steel sector is taking action in the area of synergistically combining human and robot abilities in the sense of a human-centered Industry 5.0 [73].

All relations described in this section should be analyzed through the prism of economic, ecological, and social conditions. Industry 4.0 is primarily to leave steel mills. The "lean" concept is still valid during the transition of mills to Industry $4.0[74,75]$. It is assumed that Industry 4.0 technologies will contribute to a decrease in production costs in the long term (from the start of the investment). Intelligent technologies will enable the optimization and self-improvement of processes. New technologies will be able to independently solve many, if not all, production, logistics, service, and other problems [76]. The implementation of automation and robotics in steel mills in conjunction with the IoT and AI is to lead to a higher level of development of the steel industry.

\section{Materials and Methods}

This study aims to "outline" a picture of the transformation of steelworks from level 3.0 to level 4.0. The work was based on literature review and case studies. The entire publication concerns the possibilities of developing the steel sector to Industry 4.0 and the changes already underway in steel mills, which bring them closer to steelworks 4.0. The publication is based on secondary sources of information (desk research) on the subject of changes in steel plants toward Industry 4.0. The nature of the information obtained is qualitative (qualitative research). Research belongs to the category of general and descriptive research. The research was carried out according to the following stages: preparation of information based on the literature review (databases: Web of Science-WoS, Scopus, Google Scholar), the grouping of information by topic sections, and their communication. Secondary sources of information regarding the possibilities of transforming steel mills to Industry 4.0 were expanded with cases of practical applications of Industry 4.0 technology in the steel mills. Used case studies are not representative of the whole industry. Three steel producers (strong capital groups): ArcelorMittal, Thyssenkrupp, and Tata Steel were used to show categories of investments in steel production and other processes. The choice of these capital groups (companies) was dictated by the fact that these groups were active participants in European programs for Industry 4.0 and working groups in thematic projects (information in Section 2.1). The following key was used to select the cases for analysis: we analyzed the largest steel companies in the world, one company from the remaining top 10 steel producers, and another company from the top 50 steel producers for comparison of steelworks 4.0 implementation. Random sampling was used within each group, and we used the World Steel Production-Top steel-producing companies 2019 [77].

Capital groups (companies) used as case studies were highly ranked in the World Steel Production-Top steel-producing companies 2019 [77]. ArcelorMittal, which is in the list of world steel producers, has occupied first position for many years. Tata Steel is 
also listed in the top ten steel producers (in 2019, Tata Steel ranked in ninth position), and Thyssenkrupp with a production of 12.25 million tons in 2019 was in position 35 (Figure 3).

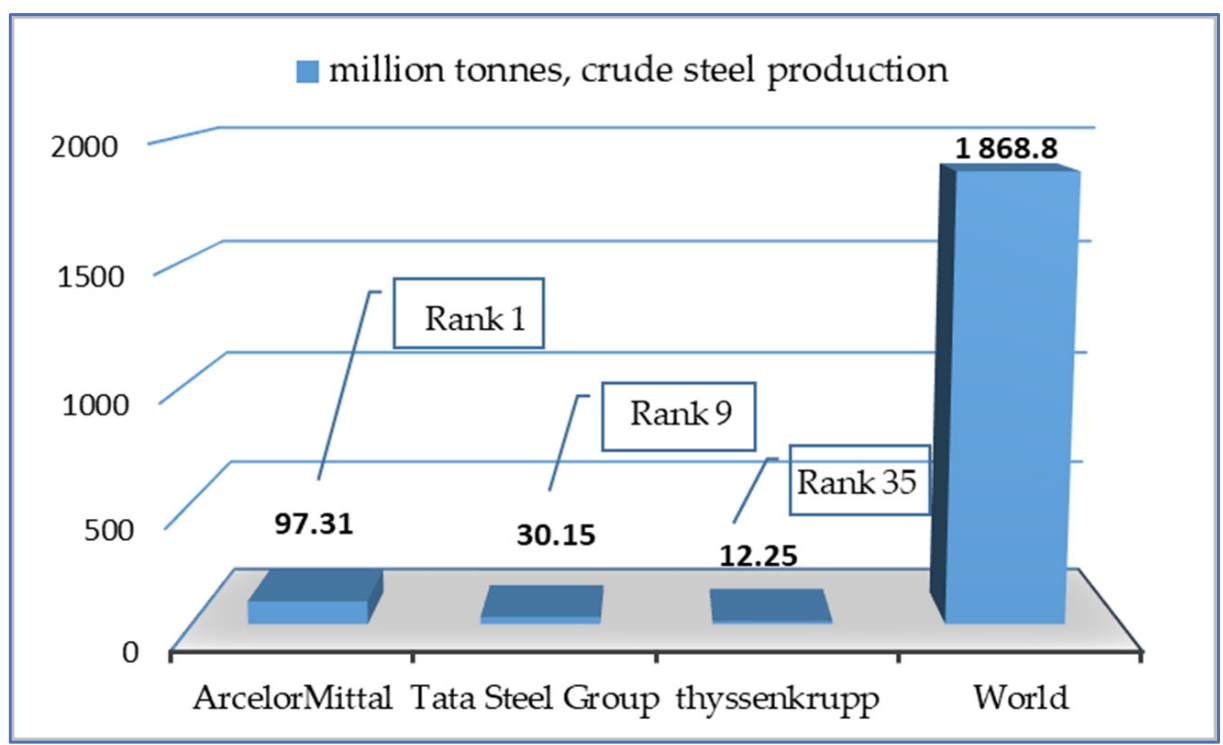

Figure 3. Used case studies in the list of top world steel producers. Source: The Figure 3 was prepared on ranking of steel producers prepared by World Steel Association [77].

The evaluation of both the collected information and the cases is included in the discussion. The conducted research explains and allows us to understand the analyzed topic. The described scope of changes in mills cannot be confirmed by statistical (quantitative) research at the present stage of the evolution of mills. Quoting from Zeman [12] and Santos et al. [13], steel mills are now in the phase between steelworks 3.0 and steelworks 4.0. Perhaps in a few years, detailed quantitative research in the steel industry should be conducted to assess the effects of investing in new technologies (KETs-key enabling technologies) [21]. In the current stage of the evolution of steel mills toward Industry 4.0, the following hypothesis has been adopted: H1: Metallurgy in highly developed countries, although it is at an intermediate stage between steelworks 3.0 and steelworks 4.0, claims development at level 4.0 by introducing changes bringing the steel industry closer to Industry 4.0; the steel mills differ in the scope of the introduced changes, and the implementation process is carried out in stages and segments; changes are happening both inside the steel mills and along the entire value chains.

We formulated the following research questions:

- Q1: To what extent are the surveyed organizations implementing changes that will transform them to the steelworks 4.0?

- Q2: Which business areas are changes leading to steelworks 4.0 being implemented?

- Q3: Is the extent of changes in the studied companies comparable?

\section{Cases of Changes in Steel Plants}

This section presents the activities of steel companies in transitioning to steelworks 4.0. The examples were compiled as cases, and the websites of steel companies such as ArcelorMittal, Thyssenkrupp, and Tata Steel were used to develop them.

Case 1: ArcelorMittal—corporate level. Source: a case based on [78]. The changes began with the creation of an organizational unit in the corporate structures for digitization, coordinated by the director of technology. The digitization committee is supported by the leaders of the R\&D groups and the information and data segments. The Commission is working to accelerate the digitization of the entire supply chain and improve the efficiency of the corporation's production and business processes. The digitization projects already implemented in the corporation [78] reduced the costs of recording, storing, and processing 
data. Thousands of sensors and devices (hardware) for collecting large datasets and their processing have been installed in the corporation. Here are some projects at ArcelorMittal. (1) Digital Excellence Centers are built close to the AM Group manufacturing facilities around the world, enabling even faster development of new technologies from prototype to maturity. (2) Collecting data from tens of thousands of "things", data used to improve delivery efficiency. Control your deliveries using IC technology based on integrated delivery metrics that measure delivery performance to customers (detailed metrics about customers and how they want to receive materials). Information is available, practically, from anywhere (investment in ArcelorMittal USA). (3) Drones are used to improve operational safety, efficiency and accuracy (investment carried out in many AM facilities). Drones check maintenance needs, minimizing the risks to our employees who would have to work at height to inspect the structure of the facility. Drones are also used to fly infrared cameras at altitudes to track energy consumption. (4) Automation leads to increased productivity and quality. Automated landfills are implemented, linked to a line schedule and transport equipment such as autonomous cranes to identify and select coils for delivery to customers, resulting in less inventory and shorter delivery times (investment in ArcelorMittal Dofasco in Canada). Fully automated sheet metal plants (in the U.S., Canada, and Mexico) provide the "scaling" required by key automotive customers. (5) AI -image recognition design and AI model are used for instant and automatic decision making for weld release in hot rolling mill (Canada plant) or AI image recognition, one for cold coil width measurement and the other for automatic grading emissions to the environment (plant in Brazil). AI saves time and leads to increased productivity. (6) Digital twinning-models used to optimize physical resources and production processes using data collected from sensors. (7) Virtual training (VT) - technology used in staff training (e.g., in the field of safety-simulations of threats or accidents at work).

Case study 2: Thyssenkrupp. Source: a case based on [79]. The corporation carries out investments worth 40 billion euros. Scope of the investment is as follows. (1) Connected (interactive) value chain: the investment concerns selected steel products (rolled strips), it consists of a digital network that tracks the entire chain from the supplier through the manufacturer to the customers. The processes are connected to a digital network in the full product life cycle. The cyber-physical system allows you to quickly respond to customer requirements regarding deadlines, even concerning the starting material already at the stage of production of semi-finished products (batch). Customers influence the production of products. Customers place orders directly in the plant's IT system and specify when their order will be processed. Customers can make changes to specifications such as product width and thickness until production begins. The interactive chain saves space and costs for storing materials and products, freeing up capital that can be used for other purposes. The investment is carried out in Hüttenwerke Krupp-Mannesmann. (2) Dialogue: productproduction. In this project, the physical world of things connects to data networks. Each product has its unique identifier and goes through the production process, transferring a large amount of data such as the customer for whom it is produced, its current processing status, and in what state he left the previous stage of the process. The dialogue between product and production is based on interfaces to the Internet. Project is implemented at the plant in Ilsenburg.

Other investments (planned): (1) Cyber-physical systems-products and machines equipped with memory to produce a specific type of product for a specific customer; all elements in the production process with access to the web; the final goal: an "intelligent factory" capable of self-management, learning, and flexible operation. (2) Designing 3D installations-digital factory for the production line for the automotive industry-assembly lines for the body, engines, and gearboxes; software tools will design entire production lines of cars including machines, robots, and handling devices on the computer. (3) Faster work thanks to 3D-hundreds of robots take care of assembling the complete product; all robots, machine islands, and controls are assembled and tested in a (three-dimensional) 3-D simulation; product image to appear at the customer's site; an approved (virtual) 
production line reduces the start-up time for a real production line. (4) Security in the industrial data space: systems (and devices) for the fast and safe transfer of large amounts of data, both internally and between companies-the final result is industrial data space, with full control of its data by users. (5) New business models with smart products: Retailers and logistics service providers are creating a digital ecosystem where everyone is constantly informed about the location, condition, and demand of goods to provide customers with everything they need. Post-project benefits: competitive advantage thanks to new business models, intelligent products, and services.

Case study 3: Tata Steel. Source case based on [80]. The group's plants are pioneers in applying advanced analytics to steel fabrication and applying digital services across entire supply chains. Basic investment: Digitization in the automotive value chain. It is an investment tailored to the needs of the automotive sector-a key recipient of steel products. The first stage of the investment is the digitization of production processes to achieve a significant reduction in resources and improve equipment efficiency (OEE). The ERP system is woven into the system of connections. System based on the megatrend: CASE. The components of digitization are three main pillars: (1) smarter technologies; (2) smarter connections; and (3) smarter services. To create smarter technologies, the Digital Innovation Center is constantly experimenting with the latest technologies such as digital twins, artificial intelligence, augmented/virtual/mixed reality, blockchain, and drones. Smarter connections require the use of the Internet of Things (IoT across the entire value chain). The vision of the future is a fully integrated ecosystem that is nurtured by the flow of information between all stakeholders. The group works with leading institutions to develop and standardize system components. Activities in the field of making steel a smarter product are part of smarter services in which systems using material data, material models, and intelligent algorithms create a data package about steel in its life cycle. The group is constantly working on the development of new digital services for smart factories, for example, quality management, dynamic process control, and predictive maintenance. The main benefit of this investment will be to increase customer value. Tata Steel monitors developments in the automotive industry and adjusts its strategic production to the requirements of the automotive market.

\section{Results of Analysis}

Based on the three case studies described in the paper, a comparative analysis between them can be conducted. Trying to compare the methods used in the three analyzed companies: ArcelorMittal, Thyssenkrupp, and Tata Steel, it can be seen that in all organizations, the main problem connected with steelworks 4.0 transition is the digitalization of all processes within an organization and in the entire supply chain. This is realized using various tools and methods, but they are concentrated on using technologies and methods such as AI, drones, virtual reality, full automatization, and industrial robots. Effects are connected with better relations with customers, which leads to an increase in customer satisfaction and organizational profit. Additionally, using digitalization, steel industry companies can achieve better supply management and lower storage costs. Some methods can lead to the faster development of new products and can have a positive impact on the quality of products. The results of the analyses are presented in Table 2. 
Table 2. Comparison of activities conducted by analyzed steel industry companies to adjust them to the steelworks 4.0 conditions.

\begin{tabular}{|c|c|c|c|}
\hline Criteria & ArcelorMittal & Thyssenkrupp & Tata Steel \\
\hline Digitalization & $\begin{array}{c}\text { Organization want to digitalize } \\
\text { the whole supply chain and all } \\
\text { business processes. }\end{array}$ & $\begin{array}{l}\text { Implementation of interactive } \\
\text { value chain. }\end{array}$ & $\begin{array}{l}\text { Applying of digital services } \\
\text { across whole supply chain. }\end{array}$ \\
\hline $\begin{array}{l}\text { Examples of } \\
\text { activities }\end{array}$ & $\begin{array}{l}\text { - } \quad \text { digital Excellence Center, } \\
\text { implementing of the IC } \\
\text { technology to control } \\
\text { devices, } \\
\text { - } \quad \text { use of drones in the safety } \\
\text { improving process, } \\
\text { fully automated sheet } \\
\text { metal plants, } \\
\text { using of Artificial } \\
\text { Intelligence in decision } \\
\text { making process, } \\
\text { using of digital twinning } \\
\text { models to optimize } \\
\text { resource management, } \\
\text { implementation of virtual } \\
\text { technology in training of } \\
\text { staff process. }\end{array}$ & $\begin{array}{l}\text { implementation of digital } \\
\text { network tracking entire chain } \\
\text { from suppliers, } \\
\text { new IT systems give customers } \\
\text { possibility to make changes in } \\
\text { specifications until production } \\
\text { begins, } \\
\text { new system gives unique } \\
\text { identifier to each product which } \\
\text { increase the traceability of the } \\
\text { parts and products, } \\
\text { Cyber-physical systems used in } \\
\text { production, } \\
\text { new possibility of 3D designing, } \\
\text { - using robots in assembling } \\
\text { process. } \\
\text { new security systems. }\end{array}$ & $\begin{array}{l}\text { digitalization of } \\
\text { - } \quad \text { production processes, } \\
\text { better integration of ERP } \\
\text { into organization, } \\
\text { - } \quad \text { implementation of system } \\
\text { based on megatrends, } \\
\text { implementation of Digital } \\
\text { Innovation Center, } \\
\text { using of artificial } \\
\text { intelligence, augmented } \\
\text { reality, block chain } \\
\text { technology and drones } \\
\text { within organization, } \\
\text { implementation of Internet } \\
\text { of Things across the whole } \\
\text { value chain. }\end{array}$ \\
\hline Effects & 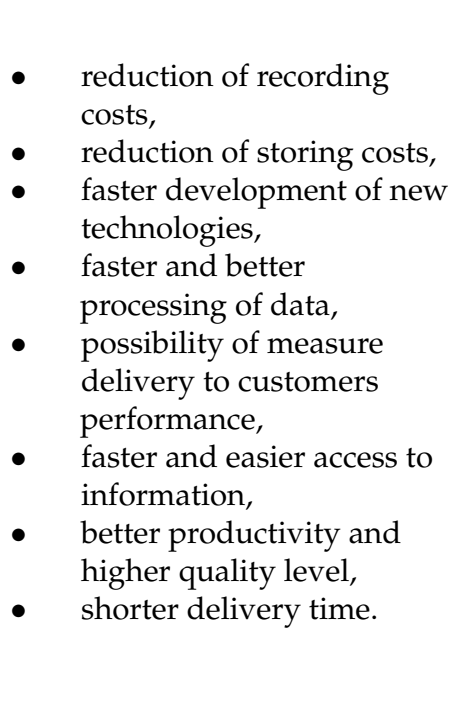 & 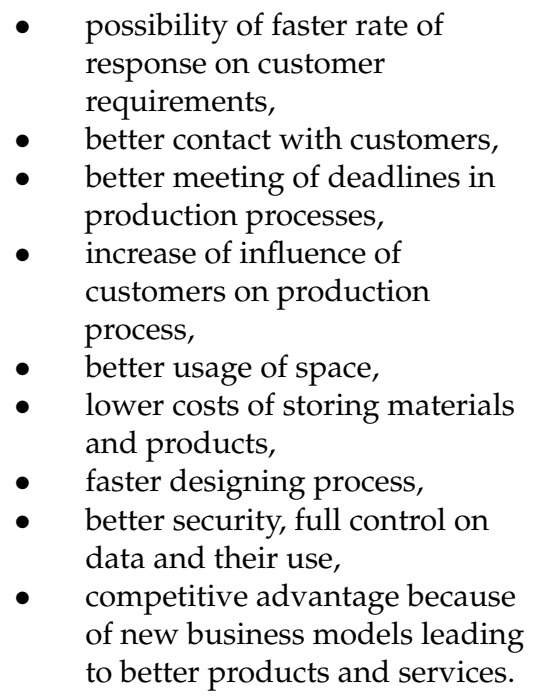 & 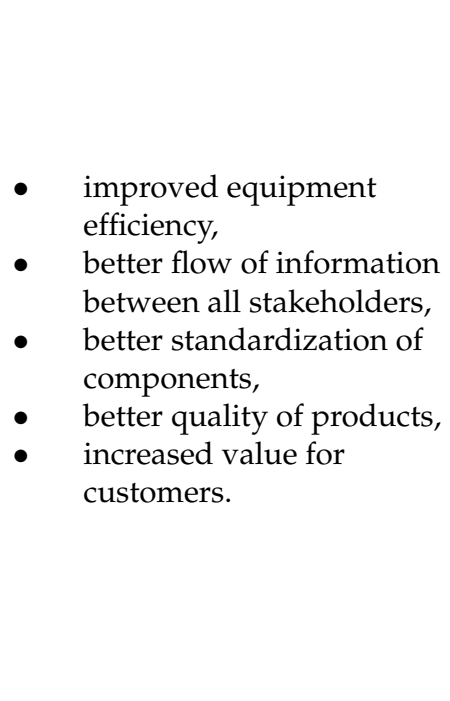 \\
\hline
\end{tabular}

Source: Based on: [78-80].

\section{Discussion}

There are industries on the market where technological progress is implemented faster and easier as well as slower industries, where the method of production implemented is very often a technical and economic barrier to radical changes. The first group includes the automotive industry, production of household appliances, clothing, footwear and food, and the second group includes the mining and quarrying industry, metallurgy, process industries (e.g., fuel industry, energy industry). In sectors where the life cycle of devices is counted in decades (steel industry, mining industry, energy industry), changes are slower than in sectors of the first group. Despite the classification of the steel sector to industries that implement new technologies slower, based on the literature review and the cited cases, it can be confirmed that the evolution of steelworks 3.0 toward steelworks 4.0 is being realized. The scope of changes is segmented and staged. Individual plants choose the scope of the changes [20]. The benchmarks on the steel market are strong capital groups that are leaders in world steel production. In the analyzed plants, the level 
of development (progress) of investments was different. However, there were common (duplicated) stages in plants. Such stages include changes at the organizational level and the developed digitization of plants [7]. The following plants have established a digitization committee and digitization centers. For many years, steel mills have been the digitization of processes, and in recent years, the digitization of entire plants and entire value chains has intensified [15].

Projects in steel mills are implemented with particular emphasis on the needs of the customer, which is the automotive sector, being one of the key recipients of steel (second position after building and construction). The automotive sector has introduced many solutions in recent years that have brought it closer to Industry 4.0 (e.g., case 2 Thyssenkrupp and case 3 Tata Steel). The cooperation of steel mills with this sector brings steel mills closer to Industry 4.0. Sectors work together to create common, modern links in the value chain. The steel industry and related (related) markets have already introduced many changes, mainly geared toward specialization and the creation of added value. In recent years, companies have offered new services related to steel processing and adaptation of products to order specifications (e.g., anti-corrosion coatings, cutting long products, assembly of steel structures), and many steel product distributors have completed investments to increase warehouse space and automate warehouses [60].

The challenges for the steel industry, and at the same time, opportunities for development are digitization and differentiation of production, full automation, robot operation, production to order, customization, improvement of value creation processes, full communication, quick access to data, and AI. The design of Industry 4.0 is very broad, it creates a set of innovative production techniques, and the principles of operation and organization of enterprises in entire value chains that are interwoven into cyber-physical systems with access to the Internet of Things and cloud computing [81-83]. The future will be created by steel mills operating in global networks with cooperating machines, warehouse systems, and production at CPS. The Fourth Industrial Revolution is characterized by the introduction of the Internet of Things (IoT) into manufacturing, which enables smart factories with vertically and horizontally integrated production systems. The characteristics of a smart plant are [81-86]:

- smart maintenance with machines that adapt to the information relayed from the devices to avoid or reduce downtime and with machines can think, according to the solutions proposed in the predictive maintenance [87-89];

- big data and smart analytics: thousands of sensors on the production line and visibility of data obtained via IIoT and CPS collect and present the data to improve operational efficiency [90];

- monitoring of devices work in real-time and process optimization: operations can be managed and maintained remotely via IIoT and by using modern technologies and systems, can suggest solutions for self-optimization and can be adapt to changing operational conditions [91];

- utilities (sustainable) management-all business activities toward energy and resources efficiency in the production of goods [92-94];

- full automatization of repetitive operations to improve on efficiencies and improve on the quality of products and flexibility of the production-requirements without complex changeovers [83]; and

- smart supply chains: an end-to-end integration of the product enables operations to manage the smart plant supply chain in terms of raw materials required, production produced and customer deliveries, mobility solutions enable the organization to manage and execute processes or decisions in real-time at the production operationsthe operations must be able to adapt to dynamic changes (e g. changes in products specifications and orders) [83].

The list of characteristics of a smart plant is wide open. Industry 4.0 technology offers many opportunities for change for many industrial sectors including steel mills. These changes in case studies should be taken as examples of changes happening in steel mills. 
The analyzed case studies do not represent the global steel industry, which is diverse, as do the economies of which the steel mills are part. The steel industry is facing significant challenges due to cost, regulations, product, and service requirements. According to Naujok and Stamm [95], challenges for metal businesses are heterogeneous product portfolio, stronger and more durable steel, shorter product-life-cycles in the downstream business, improving the European steel market (utilization of unused capacity), shorter innovation cycles, optimized service, process complexity and flexibility, sustainability efforts in the downstream business, and efficient use of resources and energy. A total of $59 \%$ of Metals CEOs (base: all respondents Metals, 37) think that digital technology will be a game-changer for the industry and will reshape competition over the next five years [96]. Digitalization is the technical achievement of the Third Industrial Revolution and Industry 4.0 is the new concept of the Fourth Industrial Revolution. Industry 3.0 allows for flexible production and a higher variety of products and programmable machines, however, flexible production in terms of quantity was still a limitation [18]. Industry 4.0 is defined as "the flexibility that exists in value-creating networks is increased by the application of Cyber-Physical Systems (CPS). This enables machines and plants to adapt their behavior to changing orders and operating conditions through self-optimization and reconfiguration" [97]. Industry 4.0 technology is not fully homogeneous, so enterprises have a large selection of solutions that characterize Industry 4.0. Some of the solutions have been presented in papers as case studies based on ArcelorMittal, Tata Steel, and Thyssenkrupp. The studies can be expanded with other examples and inspire further discussion about the level of transformation of steel mills. Initiatives under Industry 4.0 would lead to distributed, highly automated, and dynamic production networks with ten key technological enablers driving them. These enablers (KETs) are the Internet, IIoT, blockchain, big data, edge and cloud computing, robotics, human-machine interaction, artificial intelligence, and open-source software. The automation of the industrial systems is going to be achieved through interconnected cyber-physical systems (CPS) in Industry 4.0; thus, allowing the industrial infrastructure and production processes to transform into an autonomous and dynamic system [98]. In terms of digitalization, steel producers are linked with other industrial sectors. Currently, the process is not always easy because of problems with the usability of new technical solutions [99].

Technological developments, especially in the sphere of telecommunications, which have been defined as a part of "Industrial Revolution 4.0", have created completely new conditions for logistics. Solutions and concepts such as low-cost sensors, "Big Data", "IoT", "Cloud Solutions", and others have not only generated new solutions, but also, thanks to the connection with the fifth-generation mobile network (5G), have created real conditions for logistics management in real-time, regardless of the length of the supply chain. This is a new quality in the functioning of logistics, which generates further needs for practical knowledge, the indication of operating conditions and threats as well as costs of the proposed and possible solutions. Questions arise about the need and scope of implementation of concepts and solutions such as "Industry 4.0", "Logistics 4.0", "Supply Chains 4.0", and also the scope and areas as well as the effects of digital transformation and many other solutions and concepts that radically change the way of creating value, competing, and serving customers, in the steel market [100].

The first results of field research on the current state of digitalization in the European steel industry are presented in scientific publications [75]. In this paper, we present the results (online questionnaire) carried out in the steel sector in the EU (the dominant segment was large steel companies). The results are presented by Branca et al. in three areas: strategy, technical aspects, and human relations (HR) [75]. The strategic areas of change for steel producers in terms of the technology challenges of Industry 4.0 are digitization, automation, Internet of Things (IoT), analytics, cybersecurity, and process integration (PI), both for horizontal and vertical integration. Steel plants prefer (at this stage of development) digital technologies used in process chain control and where big data management is required. Industry 4.0 technologies are also applied in the areas of maintenance, administration, 
quality control, and human resource management. Some of the Industry 4.0 technologies have already been integrated into production processes and others are planned for future investments in the short term (i.e., three years) [75]. Steel producers expect that Industry 4.0 technologies will contribute to cost reduction and quality improvement, increased safety in the workplace, and environmental benefits (reduction of emissions, waste and resource consumption) - results of the green transition of the steel industry. The initiated technological investments in steelworks will result in changes in the professional profile of a steelworker. In 3-5 years, increased demand for employees with digital competencies can be expected [75].

Industry 4.0 technologies enable higher quality steel products. Using the Quality 4.0 (Q 4.0) methods and tools, organizations can adjust and improve the implementation of Industry 4.0 technologies into an organization. Quality plays an important role in the industry and benefits in real-time process monitoring and data collection [101]. Better technologies improve the quality of steel products [102]. Authors (Vannocci, et al.) made a comparison between different traditional machine learning and deep learning models in the field of flatness defects in hot steel strips (a total of about 513 strips produced in real steelworks were used for the research) [103]. A new generation of technologies fed with real data from the plant automatically detect and classify product defects and, most importantly, remember them and suggest ("show") possibilities of their elimination using decision-making algorithms based on artificial intelligence [104].

The most obvious benefit of the study for other organizations from the steel industry is our findings that in all of the analyzed organizations, the process of transition from steelworks 3.0 into steelworks 4.0 is similar, and concentrated on the digitalization of the organizations' production processes and value chain. This is a very beneficial process, leading to better fulfilment of customer requirements due to higher quality, better information flow, and decrease of many costs connected with supply chain management and product development. There is still a long way to go in the transformation process of steelworks to Industry 4.0, and already, another concept called "Industry 5.0" has emerged [72]. The evolution of industrialization from Industry 4.0 to Industry 5.0 is a result primarily of the need to expose the role of humans in cyber-physical systems. The first mention of the role of operators in Industry 4.0 appeared in Romero et al. [68,69]. It was pointed out in their paper that symbiosis between humans and new technologies is needed. The authors $[68,69]$ proposed the introduction of the human factor into cyber-physical systems. The new system construct is called human cyber-physical system (H-CPS) [69]. Referring to this construct (H-CPS), the steel sector is taking action in the area of synergistically combining human and robot abilities in the sense of a human-centered Industry $5.0[68,69,105-107]$.

Colla et al. presented the results of a field evaluation of a robotic workstation, which was designed for a complex maintenance operation that is performed daily in the steel shop. Following the assumption of Industry 5.0, the workstation presented in the paper is human-oriented [73]. Its construction followed the paradigm of the symbiosis of social and technological development (Industry 5.0). Workstations designed in this way in steelworks serve to more effectively reduce burdensome operations and improve health and safety conditions for workers, and the effects (results) are perceived by users and developers of the system [73].

In the pursuit of industry 4.0, a balance must be struck between the technology and its environmental impact. Environmental aspects in the steel sector are important in technological developments. Steel production has a number of impacts on the environment including air emissions ( $\mathrm{CO}, \mathrm{SOx}, \mathrm{NOx}, \mathrm{PM} 2)$, wastewater contaminants, hazardous wastes, and solid wastes [108]. New technologies of Industry 4.0 can help steel mills be more sustainable. The steel industry is the largest consumer of energy in the world among industrial sectors. Steel production is an energy intensive process that has a significant environmental impact $[93,94,109]$. The reduction in the availability of resources combined with the effects of global warming and climate change have increased pressure on the steel industry to reduce its overall pollution, specifically its water and carbon footprint. 


\section{Conclusions}

Industry 4.0 is a wave (megatrend) for intensive technology modernization (deep automation, robotization) and digitization in the industry. Quoting Peters [7], Industry 4.0 is a "merging of information processing with the physical process". The base technologies of this industry (KETs) enable steel mills to improve complex processes as well as their analysis in real-time, have better control over quality and safety in every area of the company's operations, and above all, instant and easier communication via P2P and M2M. In the steel industry, thanks to strong capital groups, investments in steel plants have already started, preceded by many years of the digitization of technical processes, which now facilitates process control (process management) and building cyber-physical connections in entire production systems and value chains. Our hypothesis (H1) on a segmental and partial way of steel mills from steelworks 3.0 to steelworks 4.0 was confirmed.

Based on the research, it can be said that companies in the steel industry implement Industry 4.0 solutions in a complex way. They want to digitalize all of their activities within the organization and across the whole supply chain (Q1). When we analyzed the business areas where new solutions were being implemented, they were connected with, for example, staff training, new product development, logistics and stack management, ERP implementation, use of new technologies like artificial intelligence, blockchain, augmented reality, etc. (Q2). We did not observe many differences between the analyzed companies in the case of the Industry 4.0 implementation scope. All analyzed steel companies are doing similar activities to implement new solutions. The differences were in minor particular activities-these differed in every analyzed company, but the conception and scope of change was very similar (Q3).

The steel industry will undergo further strong changes, bringing it closer to Industry 4.0 because it occupies an important place in the economies of many countries due to the strong dependence of steel producers on the markets of the recipients (steel consumers). Steel is the basic material needed to make many products, and its properties have been valued for centuries. Activities of steel mills in the economic, social, and environmental fields are part of the concept of sustainable industries and economies. The steel industry is evolving toward Industry 4.0, starting mainly with high levels of automation, which is an evolution or gradual adaptation rather than an industrial revolution. On the way to Industry 4.0, steel plants should find the symbiosis of technologies with humans according to Industry 5.0. The new level of industrial development is based on the strong relations between new technologies and sustainability and changing the place of humans in the CPS toward H-CPS. In the process of transforming the steel sector (steelworks) into Industry 4.0, a balance must be struck between the technology and its environmental impact. Ecological aspects in the steel sector have been and are a priority in the development of this industry.

Author Contributions: Conceptualization, B.G.; Methodology, B.G.; Software, B.G.; Validation, B.G.; Formal analysis, B.G. and B.G.; Investigation, B.G; Resources, B.G.; Data curation, B.G.; Writingoriginal draft preparation, B.G.; Writing-review and editing, B.G. and R.W.; Visualization, B.G., Supervision, B.G. and R.W., Funding acquisition, B.G. Both authors have read and agreed to the published version of the manuscript.

Funding: This research received no external funding.

Institutional Review Board Statement: Not applicable.

Informed Consent Statement: Not applicable.

Data Availability Statement: Data is contained within the article.

Conflicts of Interest: The authors declare no conflict of interest.

Payment: The Department of Industrial Informatics, Silesian University of Technology supported this work as a part of Statutory Research BK: 11/990/BK_21/0080. 


\section{References}

1. Schwab, K. The Fourth Industrial Revolution; World Economic forum: Cologny, Switzerland, 2016.

2. Kagermann, H.; Wahlster, W.; Helbig, J. (Eds.) Recommendations for Implementing the Strategic Initiative Industrie 4.0: Final Report of the Industrie 4.0 Working Group. In Industrie 4.0: Mit Dem Internet Der Dinge Auf Dem Weg Zur 4 Industriellen Revolution; VDI-Nachrichten: Germany, Frankfurt, April 2011.

3. Kagermann, H.; Helbig, J.; Hellinger, A.; Wahlster, W. Recommendations for Implementing the Strategic Initiative Industry 4.0: Securing the Future of German Manufacturing Industry. In Final Report of the Industry 4.0 Working Group Forschungsunion; 2013. Available online: http://www.acatech.de/fileadmin/user_upload/Baumstruktur_nach_Website/Acatech/root/de/Material_ fuer_Sonderseiten/Industrie_4.0/Final_report_Industrie_4.0_accessible.pdf (accessed on 2 February 2020).

4. Kagermann, H.; Wahlster, W.; Helbig, J. Final Report of the Industrie 4.0 Working Group; Acatech-National Academy of Science and Engineering: München, Germany, 2013. Available online: http://forschungsunion.de/pdf/industrie_4_0_final_report.pdf (accessed on 10 January 2020).

5. Kagermann, H. Change through Digitization-Value Creation in the Age of Industry 4.0. In Management of Permanent Change; Albach, H., Meffert, H., Pinkwart, A., Reichwald, R., Eds.; Springer: Wiesbaden, Germany, 2015. [CrossRef]

6. Peters, H. Application of Industry 4.0 concepts at steel production from an applied research perspective. In Proceedings of the 17th IFAC Symposium on Control, Optimization, and Automation in Mining, Mineral and Metal Processing, Wien, Austria, 1 September 2016. Available online: https:/ /tc.ifac-control.org/6/2/files/symposia/vienna-2016/mmm2016_keynotes_peters (accessed on 10 January 2021).

7. Peters, H. How could Industry 4.0 transform the Steel Industry? In Proceedings of the Future Steel Forum, Warsaw, Poland, 14-15 June 2017; PowerPoint-Präsentation. Available online: https:/ / futuresteelforum.com/ content-images/speakers/Prof.-DrHarald-Peters-Industry-4.0-transform-the-steel-industry.pdf (accessed on 10 January 2021).

8. PwC-Global Industry 4.0 Survey. What We Mean by Industry 4.0/Survey Key Findings/Blueprint for Digital Success; PwC: London, UK, 2016. Available online: https://www.pwc.com/gx/en/industries/industries-4.0/landing-page/industry-4.0-buildingyour-digital-enterprise-april-2016.pdf (accessed on 20 August 2020).

9. McKinsey. Industry 4.0: How to Navigate Digitization of the Manufacturing Sector; Report; McKinsey Company: Chicago, IL, USA, 2015. Available online: https://www.mckinsey.com/ \{\}/media/McKinsey/Business\%20Functions/Operations/Our\%20 Insights / Industry $\% 2040 \% 20 H o w \% 20$ to $\% 20$ navigate $\% 20$ digitization $\% 20$ of $\% 20$ the $\% 20$ manufacturing $\% 20$ sector / Industry-40 -How-to-navigate-digitization-of-the-manufacturing-sector.pdf (accessed on 10 June 2020).

10. Deloitte-Industry 4.0. The Industry 4.0 Paradox. Overcoming Disconnects on the Path to Digital Transformation; Deloitte Insights, Deloitte Development LLC: London, UK, 2018. Available online: https://www2.deloitte.com/content/dam/Deloitte/cn/ Documents / energy-resources / deloitte-cn-er-industry-4.0-paradox-overcoming-disconnects-en-full-report-190225.pdf (accessed on 9 September 2020).

11. Rüßmann, M.; Lorenz, M.; Gerbert, P.; Waldner, M.; Justus, J.; Engel, P.; Harnisch, M. Industry 4.0; The Boston Consulting Group: Boston, MA, USA, 2015. Available online: https://www.bcg.com/publications/2015/engineered_products_project_business_ industry_4_future_productivity_growth_manufacturing_industries (accessed on 20 June 2021).

12. Zeman, P. Industrie und Stahlbau 4.0-Ein paar Gedanken! Stahlbau 2017, 86, 84-86. [CrossRef]

13. Santos, C.; Mehrsai, A.; Barros, A.C.; Araújo, M.; Ares, E. Towards Industry 4.0: An overview of European strategic roadmaps. In Proceedings of the Manufacturing Engineering Society International Conference 2017, MESIC 2017, Vigo (Pontevedra), Spain, 28-30 June 2017.

14. Ittermann, P.; Niehaus, J. Industrie 4.0 und Wandel von Industriearbeit: Überblick Über Forschungsstand und Trendbestimmungen. In Digitalisierung Industrieller Arbeit: Die Vision Industrie 4.0 Und Ihre Sozialen Herausforderungen, 2nd ed.; Hirsch-Kreinsen, H., Niehaus, J., Ittermann, P., Eds.; Nomos Verlagsgesellschaft mbH \& Co. KG: Baden Baden, Germany, 2018 ; pp. 33-51.

15. Murri, M.; Streppa, E.; Colla, V.; Fornai, B.; Branca, T.A. Digital Transformation in European Steel Industry: State of Art and Future Scenario. Eur. Steel Ski. AgendaErasmus+ Programme Key Action 2019, 2022, 1-43.

16. Snabe Hagemann, J.; Weinelt, B. Digital transformation of industries. World Econ. Forum 2016. Available online: https://reports. weforum.org/digital-transformation/wp-content/blogs.dir/94/mp/files/pages/files/wef1601-digitaltransformation-1401 .pdf (accessed on 20 June 2021).

17. Tihinen, M.; Kääriäinen, J.; Teppola, S.; Parviainen, P. Tackling the digitization challenge: How to benefit from digitization in practice. Int. J. Inf. Syst. Proj. Manag. 2017, 5, 63-77.

18. Rojko, A. Industry 4.0 concept: Background and overview. Int. J. Interact. Mob. Technol. 2017, 11, 77-90. [CrossRef]

19. Herzog, K.; Winter, G.; Kurka, G.; Ankermann, K.; Binder, R.; Ringhofer, M.; Maierhofer, A.; Flick, A. The Digitization of Steel Production. BHM BHM Berg Und Hüttenmännische Mon. 2017, 162, 504-513. [CrossRef]

20. Gajdzik, B.; Grabowska, S.; Saniuk, S. A Theoretical Framework for Industry 4.0 and Its Implementation with Selected Practical Schedules. Energies 2021, 14, 940. [CrossRef]

21. Zhou, K.; Liu, T.; Zhou, L. Industry 4.0: Towards Future Industrial Opportunities and Challenges. In Proceedings of the International Conference on Fuzzy Systems and Knowledge Discovery, Zhangjiajie, China, 15-17 August 2016; pp. $2147-2152$.

22. Berger, R. Industry 4.0-The New Industrial Revolution-How Europe Will Succeed. Roland Berger Strategy Consultants. 2014. Available online: http:/ / www.iberglobal.com/files/Roland_Berger_Industry.pdf (accessed on 20 June 2021). 
23. Hermann, M.; Pentek, T.; Otto, B. Design Principles for Industrie 4.0 Scenarios; A Literature Review, Working Paper No. 01/2015; Technische Universität Dortmund Fakultät Maschinenbau. Available online: http:/ /www.iim.mb.tu-dortmund.de/cms/de/ forschung/Arbeitsberichte/Design-Principles-for-Industrie-4_0-Scenarios.pdf (accessed on 15 June 2021).

24. Plattform Industrie 4.0, 2014: Industrie 4.0. Whitepaper FuE-Themen. Available online: http://www.plattform-i40.de/sites/ default/files/Whitepaper_Forschung\%20Stand\%203\%20April\%202014_0.pdf (accessed on 30 November 2014).

25. Advanced Technologies for Industry. Available online: https:/ / ati.ec.europa.eu (accessed on 24 June 2021).

26. Cluster Collaboration. Available online: https://www.clustercollaboration.eu/news/advanced-technologies-industry-atiwebsite-launched (accessed on 20 February 2021).

27. Besiekierska, A.; Gorgol, M. Platformy dla Przemysłu 4.0 w Skali Polski i Niemiec. Available online: https:/ /automatykaonline. pl/Artykuly/Prawo-i-normy/Platformy-dla-Przemyslu-4.0-w-skali-Polski-i-Niemiec (accessed on 26 November 2019 ).

28. Stahlmarkt 2016. Stahl 2025-Quo vadis? PwCFrankf. Am. Main 2016, 10. Available online: https://www.pwc.at/de/branchen/ assets/industrielle-produktion/folder-stahlmarkt-2016.pdf (accessed on 15 January 2020).

29. European Commission. Steel: Preserving Sustainable Jobs and Growth in Europe; COM (2016) 155 Final; European Commission: Brussels, Belgium, 16 March 2016.

30. European Commission. A New Industrial Strategy for Europe; COM (2020) 102 Final; European Commission: Brussels, Belgium, 10 March 2020.

31. European Commission. Action Plan for a Competitive and Sustainable Steel Industry in Europe; COM (2013) 407 Final; European Commission: Brussels, Belgium, 11 June 2021.

32. Digital Twin Technology in the Steel Industry. Available online: https:/ / www.estep.eu/assets/Final-Programme-Digital-TwinWS-21-22-November.pdf (accessed on 20 December 2019).

33. Branca, T.A.; Fornai, B.; Colla, V.; Murri, M.M.; Streppa, E.; Schröder, A. The Challenge of Digitalisation in the Steel Sector. Metals 2020, 10, 288. Available online: https://www.mdpi.com/2075-4701/10/2/288/htm (accessed on 15 June 2021). [CrossRef]

34. Hecht, M. Industrie 4.0 der Dillinger Weg. Stahl Eisen 2017, 137. Available online: https://pure.unileoben.ac.at/portal/files/5379 849/ AC15701207.pdf (accessed on 15 June 2021).

35. Industry 4.0 in the European Iron and Steel Industry: Towards an Overview of Implementations and Perspectives (fraunhofer.de). Available online: https://www.isi.fraunhofer.de/content/dam/isi/dokumente/cce/2018/Industry-4-0-Implementation-andPerspectives_Steel-Industry_Working\%20document.pdf (accessed on 10 January 2021).

36. Research Fund for Coal and Steel, RFCS, 2003-2014, Summaries of RFCS Projects: 2003-2014. Available online: http:/ / ec.europa. $\mathrm{eu} /$ research/industrial_technologies/pdf/rfcs/summaries-rfcs_en.pdf (accessed on 8 January 2018).

37. Research Fund for Coal and Steel, RFCS, 2015-2016, Synopsis of the RFCS projects 2015-2016. Available online: http:/ / ec.europa. eu/research/industrial_technologies/pdf/rfcs/synopsis_projects_2015-16.pdf (accessed on 8 January 2018).

38. European Commission. 2018 Community Research and Development Information Service CORDIS. Available online: https: / / cordis.europa.eu/projects (accessed on 5 March 2018).

39. European Commission. Research and Innovation Funding 2014-2020. Available online: https://ec.europa.eu/research/fp7 /index_en.cfm (accessed on 5 March 2018).

40. Arens, M.; Neef, C.; Beckert, B.; Hirzel, S. Perspectives for digitising energy-intensive industries-findings from the European iron and steel industry. ECEEE Ind. Summer Study 2018, 259-268. Available online: https://www.eceee.org/library/conference_ proceedings / eceee_Industrial_Summer_Study /2018/2-sustainable-production-towards-a-circular-economy / perspectivesfor-digitising-energy-intensive-industries-findings-from-the-european-iron-and-steel-industry/2018/2-118-18_Arens.pdf/ (accessed on 15 January 2021).

41. Neef, C.; Hirzel, S.; Arens, M. Industry 4.0 in the European Iron and Steel Industry: Towards an Overview of Implementation and Perspectives; Fraunhofer, Institute for Systems and Innovation Research ISI: Karlsruhe, Germany, 2018.

42. Geetha Devi, K.V.; Thakur, S.S.; Singh, S.K. Assessing the performances of vendor firms by optimization technique industry 4.0 GSC architectures. Int. J. Soc. Ecol. Sustain. Dev. 2021, 12, 1-10. [CrossRef]

43. Blueprint ‘New Skills Agenda Steel': Industry-driven sustainable European Steel Skills Agenda and Strategy (ESSA). Available online: https: / / www.estep.eu/essa (accessed on 5 February 2021).

44. Bielański, A. Podstawy Chemii Nieorganicznej; Wyd. 5. T. 2; PWN: Warsow, Poland, 2002; p. 921.

45. Chirumalla, K. Building digitally-enabled process innovation in the process industries: A dynamic capabilities approach. Technovation 2021, 105, 102256. [CrossRef]

46. Worldwide IT Industry 2016 Predictions: Leading Digital Transformation to Scale; IDC FutureScape: New York, NY, USA, 2016 ; p. 125.

47. Adamczewski, P. Knowledge Management in Intelligent Organizations in the Times of the Digital Transformation-Findings of the Research on the Polish SME Sector. In Zeszyty Naukowe Wyższej Szkoły Bankowej w Poznaniu; Wyższa Szkoła Bankowa w Poznaniu: Poznań, Poland, 2017; pp. 53-68.

48. Torn, I.A.R.; Vaneker, T.H.J. Mass Personalization with Industry 4.0 by SMEs: A concept for collaborative networks. Procedia Manuf. 2019, 135-141, 2351-9789. [CrossRef]

49. KETs Information from European Parliament. Available online: https://www.europarl.europa.eu/RegData/etudes/STUD/2014 /536282/IPOL_STU\%282014\%29536282_EN.pdf (accessed on 15 June 2021).

50. Senn, C. The Nine Pillars of Industry 4.0. Available online: https://www.idashboards.com/blog/2019/07/31/the-pillars-ofindustry-4-0 (accessed on 5 January 2020). 
51. Erboz, G. How to Define Industry 4.0: Main Pillars of Industry 4.0. In Proceedings of the 7th International Conference on Management (ICoM 2017), Nitra, Slovakia, 1 June 2017. Available online: https:/ /www.researchgate.net/publication/32655738 8_How_To_Define_Industry_40_Main_Pillars_Of_Industry_40 (accessed on 9 June 2019).

52. Burrell, D. Principles of Industry 4.0 and the 9 Pillars. Available online: https:/ /www.plextek.com/insights/insights-insights / industry-4-0-and-the-9-pillars (accessed on 7 February 2019).

53. Culot, G.; Nassimbeni, G.; Orzes, G.; Sartor, M. Behind the Definition of Industry 4.0: Analysis and Open Questions. Int. J. Prod. Econ. 2020. [CrossRef]

54. Sniderman, B.; Mahto, M.; Cotteleer, M.J. Industry 4.0 and manufacturing ecosystems. Exploring the world of connected enterprises. Deloitte Dev. LLC 2016, 1, 1-24. Available online: https:/ /www2.deloitte.com/content/dam/insights/us/articles/ manufacturing-ecosystems-exploring-world-connected-enterprises/DUP_2898_Industry4.0ManufacturingEcosystems.pdf (accessed on 5 January 2021).

55. Saniuk, S.; Grabowska, S.; Gajdzik, B. Social Expectations and Market Changes in the Context of Developing the Industry 4.0 Concept. Sustainability 2020, 12, 1362. [CrossRef]

56. Gajdzik, B.; Grabowska, S.; Saniuk, S.; Wieczorek, T. Sustainable Development and Industry 4.0: A Bibliometric Analysis Identifying Key Scientific Problems of the Sustainable Industry 4.0. Energies 2020, 13, 4254. [CrossRef]

57. Gajdzik, B. Environmental aspects, strategies and waste logistic system based on the example of metallurgical company. Metalurgija 2009, 48, 63-67.

58. Towards Competitive and Clean European Steel; Commission Staff Working Document, 353 Final; SWD: Brussels, Belgium, 2021. Available online: https:/ / ec.europa.eu/info/sites/default/files/swd-competitive-clean-european-steel_en.pdf (accessed on 24 June 2021).

59. Ocieczek, W.; Gajdzik, B. Social responsibility of business in Industry 4.0. WSHumanitas. Manag. 2019, 89-102. [CrossRef]

60. Garbarz, B.; Szulc, W.; Rębiasz, B. Prognozy rozwoju popytu i podaży na rynku stalowych wyrobów hutniczych w Polsce (Forecasts of supply and demand development on the finished steel market in Poland). Hut. Wiadomości. Hut. 2007, 74, 125-132.

61. World Economic Forum. Localized Microfactories-The New Face of Globalised Manufacturing. Available online: https: / / www.weforum.org/agenda/2019/06/localized-micro-factories-entrepreneurs-and-consumers (accessed on 11 June 2019).

62. Blueprint for Sectoral Cooperation on Skills: Towards an EU Strategy Addressing the Skills Needs of the Steel Sector. In European Vision on Steel-Related Skills and Supporting Actions to Solve the Skills Gap Today and Tomorrow in Europe; European Commission Executive Agency for Small and Medium-sized Enterprises (EASME) Unit A1—COSME: Brussels, Belgium, 2020 ; p. 74.

63. Gajdzik, B. Visions and Directions for the Development of Logistics 4.0 in Context 4.0 Industrial Revolution (level 4.0-L.4.0). In Production Management and Packaging. Food safety and Industry 4.0; Walaszczyk, A., Jałmużna, I., Lewandowski, J., Eds.; Politechnika Łódzka: Łódź, Poland, 2019; pp. 69-79. Available online: http:/ / cybra.lodz.pl/publication/19228 (accessed on 15 June 2021).

64. Gajdzik, B.; Grzybowska, K. Example models of building trust in supply chains of metalurgical enterprises. Metalurgija 2012, 51, 563-566.

65. Grzybowska, K.; Gajdzik, B. SECI model and facilitation in change management in metallurgical enterprise. Metalurgija 2013, 52, 275-278.

66. Cygler, J.; Gajdzik, B.; Sroka, W. Coopetition as a development stimulator of enterprises in the networked steel sector. Metalurgija 2014, 53, 383-386.

67. Biały, W.; Gajdzik, B.; Jimeno, C.; Romanyshyn, L. Engineer 4.0 in a Metallurgical Enterprise. In Multidisciplinary Aspects of production Engineering. Monograph. Engineering and Technology. Pt. 1; Biały, W., Ed.; Sciendo: Warszawa, Poland, $2019 ;$ pp. 172-182. [CrossRef]

68. Romero, D.; Noran, O.; Stahre, J.; Bernus, P.; Fast-Berglund, Å. Towards a human-centred reference architecture for next generation balanced automation systems: Human-automation symbiosis. Adv. Prod. Manag. Syst. 2015, 460, 556-566.

69. Romero, D.; Bernus, P.; Noran, O.; Stahre, J.; Fast-Berglund, Å. The Operator 4.0: Human Cyber-Physical Systems \& Adaptive Automation Towards Human-Automation Symbiosis Work Systems. In Proceedings of the IFIP International Conference on Advances in Production Management Systems-APMS. Proceedings of Advances in Production Management Systems: Initiatives for a Sustainable World, Novi Sad, Serbia, 3 September 2016; pp. 677-686. Available online: https:/ /link.springer.com/chapter/ 10.1007/978-3-319-51133-7_80 (accessed on 20 February 2021).

70. Ruppert, T.; Jaskó, S.; Holczinger, T.; Abonyi, J. Enabling Technologies for Operator 4.0: A Survey. Apply Sci. 2018, 8, 1650. Available online: https:/ / www.mdpi.com/2076-3417/8/9/1650 (accessed on 15 June 2021). [CrossRef]

71. Romero, D.; Stahre, J.; Wuest, T.; Noran, O.; Bernus, P.; Fast-Berglund, Å.; Gorecky, D. Towards an Operator 4.0 Typology: A Human-Centric Perspective on the Fourth Industrial Revolution Technologies. In Proceedings of the International Conference on Computers and Industrial Engineering (CIE46), Tianjin, China, 29 October 2016; pp. 1-11.

72. Industry 5.0 Towards A Sustainable, Human Centric and Resilient European industry; European Commission: Brussels, Belgium, 2021. Available online: https:/ / op.europa.eu/en/publication-detail/-/publication/aed3280d-70fe-11eb-9ac9-01aa75ed71a1 /language-en/format-PDF/source-search (accessed on 15 June 2021).

73. Colla, V.; Matino, R.; Schröder, A.J.; Schivalocchi, M.; Romaniello, L. Human-Centered Robotic Development in the Steel Shop: Poprawa zdrowia, bezpieczeństwa i umiejętności cyfrowych w miejscu pracy. Metals 2021, 11, 647. [CrossRef] 
74. Wagner, T.; Herrmann, C.; Thiede, S. Industry 4.0 impacts on lean production systems. Elsevier, 50-th CIRP Conference of manufacturing Systems. Preced. CIRP 2017, 63. [CrossRef]

75. Branca, A.; Fornai, B.; Colla, V.; Murri, M.M.; Streppa, E.; Schröder, A.J. Current and future aspects of the digital transformation in the European Steel Industry. Matériaux Tech. 2020, 108, 508. [CrossRef]

76. Stadnicka, D.; Antonelli, D. Discussion on lean approach implementation in a collaborative man-robot workstation. In Proceedings of the Sixth International Conference on Business Sustainability, Management, Technology and Learning for Individuals, Organisations and Society in Turbulent Environment, Povoa de Varzim, Portugal, 16-18 November 2016.

77. 2020 World Steel in Figures. Data Finalised 30 April 2020. In Top Steel-Producing Companies 2019; World Steel Association: Brussels, Belgium, 2020; p. 8.

78. Corporate ArcelorMittal Website. Available online: https://corporate.arcelormittal.com/media/case-studies/industry-4-0 (accessed on 20 February 2021).

79. Company Thyssenkrupp Website. Available online: https://www.thyssenkrupp.com/en/company/innovation/industry-4-0 (accessed on 4 February 2021).

80. TataSteel Website. Available online: https://www.tatasteeleurope.com/ts/automotive/industry-themes/digitalisation (accessed on 4 February 2021).

81. Lee, J.; Bagheri, B.; Kao, H. Research Letters: A Cyber-Physical Systems architecture for Industry 4.0-based manufacturing systems. Manuf. Lett. 2015, 3, 18-23. [CrossRef]

82. Liu, Y.; Peng, Y.; Wang, B.; Yao, S.; Liu, Z. Review on cyber-physical systems. IEEE CAA J. Autom. Sin. 2017, 4, 27-40. [CrossRef]

83. Govender, E.; Telukdarie, A.; Sishi, M.N. Approach for Implementing Industry 4.0 Framework in the Steel Industry. In Proceedings of the 2019 IEEE International Conference on Industrial Engineering and Engineering Management (IEEM), Macao, China, 15-18 December 2019. Available online: https:/ / ieeexplore.ieee.org/stamp/stamp.jsp?tp=\&arnumber=8978492 (accessed on 21 June 2021). [CrossRef]

84. Henning, K. Recommendations for Implementing the Strategic Initiative Industrie 4.0. 2013. Available online: https://www.din. de/blob/76902/e8cac883f42bf28536e7e8165993f1fd/recommendations-for-implementing-industry-4-0-data.pdf (accessed on 20 February 2021).

85. Shrouf, F.; Ordieres, J.; Miragliotta, G. Smart factories in Industry 4.0: A review of the concept and of energy management approached in production based on the internet of things paradigm. In Proceedings of the 2014 IEEE International Conference on Industrial Engineering and Engineering Management, Selangor, Malaysia, 9-12 December 2014.

86. Olalekan, O.; Afees, O.; Ayodele, S. An Empirical Analysis of the Contribution of Mining Sector to Economic Development in Nigeria. Khazar J. Humanit. Soc. Sci. 2016, 19, 1. [CrossRef]

87. Patel, M. The Future of Maintenance; White Paper; Infosys: Bengaluru, India, 2018. Available online: https://www.infosys.com/ industries/aerospace-defense/white-papers/Documents/enabled-predictive-maintenance.pdf (accessed on 16 July 2019 ).

88. Rødseth, H.; Eleftheriadis, R.J.; Li, Z.; Li, J. Smart Maintenance in Asset Management-Application with Deep Learning. In International Workshop of Advanced Manufacturing and Automation. IWAMA 2019: Advanced Manufacturing and Automation IX; Springer: Singapore, 2020; pp. 608-615.

89. Bousdekis, A.; Lepenioti, K.; Ntalaperas, D.; Vergeti, D.; Apostolou, D.; Boursinos, V. A RAMI 4.0 View of Predictive Maintenance: Software Architecture, Platform and Case Study in Steel Industry. In Advanced Information Systems Engineering Workshops. CAiSE 2019. Lecture Notes in Business Information Processing; Proper, H., Stirna, J., Eds.; Springer: Cham, Switzerland, 2019 ; Volume 349. [CrossRef]

90. Lee, J.; Kao, H.-A.; Yang, S. Service Innovation and Smart Analytics for Industry 4.0 and Big Data Environment. In Procedia CIRP; Elsevier B.V.: Windsor, Ontario, Canada, 2014; pp. 3-8.

91. Dellnitz, M.; Dumitrescu, R.; Flaßkamp, K.; Gausemeier, J.; Hartmann, P.; Iwanek, P.; Korf, S.; Krüger, M.; Ober-Blöbaum, S.; Porrmann, M.; et al. The Paradigm of Self-Optimization. In Design Methodology for Intelligent Technical Systems. Lecture Notes in Mechanical Engineering; Gausemeier, J., Rammig, F., Schäfer, W., Eds.; Springer: Heidelberg/Berlin, Germany, 2014 ; pp. 1-25. [CrossRef]

92. Miśkiewicz, R.; Wolniak, R. Practical application of the Industry 4.0 concept in a steel company. Sustainability $2020,12,5776$. [CrossRef]

93. Wolniak, R.; Saniuk, S.; Grabowska, S.; Gajdzik, B. Identification of Energy Efficiency Trends in the Context of the Development of Industry 4.0 Using the Polish Steel Sector as an Example. Energies 2020, 13, 2867. [CrossRef]

94. Gajdzik, B.; Sroka, W. Resource Intensity vs. Investment in Production Installations-The Case of the Steel Industry in Poland. Energies 2021, 14, 443. [CrossRef]

95. Naujok, N.; Stamm, H. Industry 4.0 in Steel: Status, Strategy, Roadmap and Capabilities. 14-th June 2017. Keynote Presentation Future Steel Forum, Warsaw; PwC Strategy: London, UK, 2017. Available online: https: / futuresteelforum.com/content-images/ speakers/Dr-Nils-Naujok-Holger-Stamm-Industry-4.0-in-steel.pdf (accessed on 23 March 2021).

96. PwC 20th Annual Global CEO Survey: Key Findings from the Global Metals Sector; PwC: London, UK, 2017.

97. Platform Industrie 4.0. Available online: https://www.plattform-i40.de/I40/Navigation/EN/Home/home.html (accessed on 26 February 2019). 
98. Davies, R. Industry 4.0 digitalisation for productivity and growth. European Parliament PE 568.337. Eur. Parliam. Res. Serv. 2015, 1. Available online: https://www.europarl.europa.eu/RegData/etudes/BRIE/2015/568337/EPRS_BRI(2015)568337_EN.pdf (accessed on 20 June 2021).

99. Gajdzik, B.; Wolniak, R. Digitalisation and Innovation in the Steel Industry in Poland-Selected Tools of ICT in an Analysis of Statistical Data and a Case Study. Energies 2021, 14, 334. [CrossRef]

100. Ślusarczyk, B.; Tvaronavičienè, M.; Ul Haque, A.; Oláh, J. Predictors of industry 4.0 technologies affecting logistic enterprises' performance: International perspective from economic lens. Technol. Econ. Dev. Econ. 2020, 26, 1263-1283. [CrossRef]

101. Küpper, D.; Knizek, C.; Ryeson, D.; Noecker, J.; Quality 4.0 Takes More than Technology. ASQ 2019. Available online: https://image-src.bcg.com/Images/BCG-Quality-4.0-Takes-More-Than-Technology-Aug-2019_tcm9-224161.pdf (accessed on 21 June 2021).

102. Gajdzik, B.; Sitko, J. An analysis of the causes of complaints about steel sheets in metallurgical product quality management systems. Metalurgija 2014, 53, 135-138.

103. Vannocci, M.; Ritacco, A.; Castellano, A.; Galli, F.; Vannucci, M.; Iannino, V.; Colla, V. Flatness Defect Detection and Classification in Hot Rolled Steel Strips Using Convolutional NeuralNetworks. In Advances in Computational Intelligence, IWANN 2019, Lecture Notes in Computer Science; Rojas, I., Joya, G., Catala, A., Eds.; Springer: Cham, Switzerland, 2019; p. 11507.

104. Duft, P. Durana, Algorytmy decyzyjne oparte na sztucznej inteligencji, zautomatyzowane systemy produkcyjne i innowacje oparte na big data w zrównoważonym przemyśle 4.0. Econ. Manag. Finan. Mark. 2020, 15, 9-18.

105. Skobelev, P.; Borovik, S.Y. On the way from Industry 4.0 to Industry 5.0: From digital manufacturing to digital society. Industry $4.02017,2,307-311$.

106. Shelzer, R. What Is Industry 5.0-And How Will It Affect Manufacturers. 2017. Available online: https:/ / gesrepair.com/industry5-0-will-affect-manufacturers (accessed on 21 June 2021).

107. Nahavandi, S. Industry 5.0-A Human-Centric Solution. Sustainability 2019, 11, 4371. [CrossRef]

108. Gajdzik, B.; Wyciślik, A. Assessment of environmental aspects in a metallurgical enterprise. Metalurgija 2012, 51, 537-540.

109. Conejo, A.N.; Birat, J.-P.; Dutta, A. A review of the current environmental challenges of the steel industry and its value chain. J. Environ. Manag. 2020, 259, 109782. [CrossRef] [PubMed] 